\title{
再建：上顎（II） 163〜168
}

\section{座長のまとめ}

一色 信彦 (京都大学・形成外科)

本群では频顔面領域術後欠損に対する義頻，エピテー ゼなどの問題が論ぜられた。

163 : 白井らは エピテーゼの使用状況を調查し、エピ テーゼを作ってむ使用しない場合，その問題はどこにあ るのかを追究している。エピテーゼ一般についての質問 であるが，長期使用で再製作せねばならぬ時に，以前と ったモールドを再利用するのかとの資問（後藤）に注 井ならびに瀬戸よりェピテーゼの契命㤝在せいぜい 2 年余で，またその閒, 久損側の変化も考えられ，再製作 に際しては新たに作しなおすと虑答があった。

164 : 中村らも前演題と同一施設からだが，エピテー ゼ不使用の因として心理面をより深く調べ，エピテーゼ 製作前の心理テストの結果加, 患者の消極的心理面に 問題がある棣だと述べている。では使用中止が予想され る症例にはどう対虑するのかとの砂川の篮問にはエピテ 一ゼ製作前に十分な説明が特に必要との応答があった。 たしかに折角作ってる使用しないと判っているのに, 作 るのは無䭾でそのためのスクリーニングが必要という面 むあろらが，それ以上に不使用ないし使用中止となら 様，より以前から十分群明を行なって効果をあげるとい う䅡極面がより重要なのであろう。

165〜168は補緅と音声に関するものである。

165 : 海野らは義額装着前後で 発語明膫度がどう変化 するかを欠損種類別に調べた。白川より顔面欠損が合件 する場合はどうなるか，また義額の形態と語明度との関 係化ついて放問があり，演者より顔面欠提症例は含まれ ておらず，形態に関しては大部分が中空型で，天蓋開放
型は少なく，両者の比較検剖はしていないとの事であっ た。これに関連し，野村は両型間に語明度の美を諗めな かったとの追加があった。

166 : 大沢ら梳上頻全摘後の補緅物による 言語改善を 空気力学的方法, ファイバスコピー, 語明度などから検 討し，一般に補䜌物により著明改善するが，手術切除範 囲の広いむの，とくに軟口蓋に及ぶものでは困難を伴な うとの事であった。

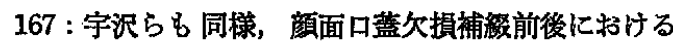
語明度の変化をしらへ， 久損程度との関係を云々してい るが，颜面欠損合併の有無と語明度は必ずしもはっきり 相関しないとのべている。これら演題に関連し，筥明度 検査の際には視力障害のある患者むいるので注意功必要 との追加（野村）もあった。

168 : 糟谷らは筋肉皮茾で再建した舌が, 萎縮して来 た場合，上影にプレートを装着し，発音の補助となった 症例を示した。

プロテーゼと言語の問題袮従来それほど省みられなか った嫌いがないでもない。今回の演題は主にその実態調 查ともいうべきものが多く, 今後の研究発展のための基 䂾的資料を提供している。

今後はプロテーゼ装着によっても語明度がなお十分に 改善しない症例の原因柱どこにあるのか，共鳴の問題か 気流漏出か，鼻咽腔閉鎖機能や構音運動に異常はないの かなど原因追究に向って研究が進められるべきであり， より学際的共同研究が要求されて行くであらう。 


\section{3. 当科で製作したェピテーゼ53例の使用状況について}

白井 潔・菊田ひとみ・吉野壮一郎・中村 広一 松浦 正朗・瀬戸 晥一（鶴見大学・第 1 口腔外科） 多名部哲博

（関東労災病院 - 歯科口腔外科）

顔面久損を人工材料で補鏆するエピテーゼは精繳な彫 刻が可能で，かつ状況に空じ作り換え出きる等の長所が あるが，可撤式であるため身体との一体感に元しい。ま た人間の尊皦の象徵である顔に装用させるためエピテー ゼの受容を高めるためには解決すべき多くの問題点があ る。当科では，よりよいエピテーゼ製作のために定期的 に使用状況, 患者の意見等を調查しておる，その結果を 報告する。

\section{調查方法}

製作後 6 カ月以上経過した 53 例を可能な限り面接に て，一部同一内容のアンケートを郵送し，種々の質間に 対する解答を求めた。対象患者53例の内訳けは, 男35名, 女18名で10代が最も少なく，50代，60代が多かった。

\section{結 果}

a) 使用状況：調查表を回收できたのは29名で現在使 用中13名, 使用中止12名, まったく使用しなかった者 4 名であった。男女別では使用群は男が，非使用群は女が 多かった。我々江顔面欠損を図1亿示すように, 皮膚欠 損 (F) と宿回（C）の2つの因子を組み合せて表現す る FC 分類により分類している。表 2 はエピテーゼの 大きさと使用状況であるが，小さな欠損よりもむしろ， 欠損の大きい者の方が使用頻度が高かった。

b) エピテーゼに対する意見 : 使用群ではエピテーゼ に対し，满足している7名，不满を持ちながらも使用し ている者 6 名だった。これら患者はエピテーゼの利点と して, 自然感が得られる (11名) 社会参加ができた（4 名）取り报いが便利（4名）病気が治った気分になれた （3名）等を挙げていた。不満として恃，脱落（3名） 正しい眼の位置に装用が困難, 固定法, 発赤疼痛（各 2 名）等が举げられた。使用群 13 名中 9 名は 5 年以上, 3 名が 3 年以上の装用者であり，9名は 2 個以上のエピテ 一ゼの経験者であった。材料としては，シリコーン樹脂 11例，ポリウレタン樹脂 2 例で，1 年以上使用したもの で注退色，変色，軟化が認められたものがあったが，著 しい変盾はなかった。非使用群では，エピテーゼに不満 とした者11名，満足 1 名，無回答 4 名であった。エピテ 一ゼの利点として自然感 (3名) 取り扱心便利 (1名) が挙げられたが，不満点として他人の視線が気になる （7名）脱落, 発赤疼痛, エピテーゼの色が合っていな い(各 3 名) 等が举げられた。使用中止例では 1 例を除 いて 6 カ月以内装用を中止していた。まったく使用し なかった者 4 名中 3 名は $\mathrm{F}_{1} \mathrm{C}_{0}$ の小さな欠損でかっ10代 の患者だった。
今回の調查で明らかになった事として，5 年以上装用 9 名, 3 年以上 3 名の長期使用者がおり，これらの患者 は番美性や維持に多少の不満を感じていても，エピテー ゼを自分の身体の一部として使用し無くてはならない物 としていた。

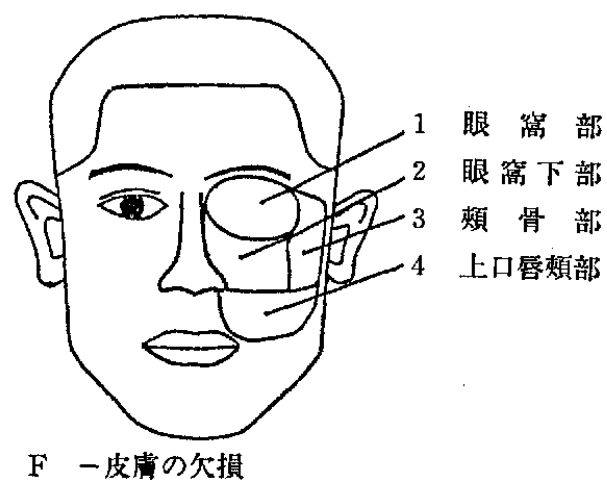

C 一皮者残存部宿四

【F】 Facial Skin Defect

$\mathrm{F}_{1}$ 眼窩部に欠損があるもの

$F_{1}$ 深以欠損

$\mathrm{F}_{1 \mathrm{a}}$ 浅い欠損

$\mathrm{F}_{1 \mathrm{~b}}$ 眼瞼の不十分な再建による久損

$\mathrm{F}_{2}$ 眼窝下部に皮盧欠損があるもの

Fs 煩骨部に皮席欠損があるもの

$\mathrm{F}_{4}$ 上口唇煩部に皮虔欠損があるもの

(C) Concavity

$\mathrm{C}_{1}$ 眼窩部に宿凹があるもの

$\mathrm{C}_{2}$ 眼窝下部宿凹があるもの

$\mathrm{C}_{3}$ 煩骨部に陥凹があるもの

C4 上口唇頝部门陌凹があるもの

図 1 眼窩上類部の欠損の分類

表 2 エピテーゼの大きさと使用状況

\begin{tabular}{|c|c|c|c|c|}
\hline & \multirow{2}{*}{ 使用群 } & \multicolumn{2}{|c|}{ 非使用群 } & エピテ \\
\hline & & 中止 & 應わだ & 大きさ \\
\hline $\mathrm{FC}_{1}$ 眼 窝 部 & 6 & 7 & 3 & 小 \\
\hline $\mathrm{FC}_{12}$ 眼窝+眼窩下部 & 1 & 1 & ～ & \\
\hline $\mathrm{FC}_{1-3}$ 眼䆬骨+部 & 6 & 4 & 1 & \\
\hline 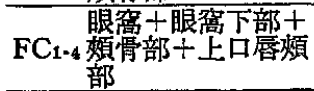 & ノ & Y & I & 大 \\
\hline
\end{tabular}




\title{
164. エピテーゼによる顔面欠損患者の治療過程における心理的 諸問題について
}

\author{
中村 広一・菊田ひとみ・尾口 仁志・白井 潔 \\ 松浦 正朗・瀬戸 晥一（鶴見大学・第 1 口腔外科）
}

日本人においては，欧米人に比して他人の視線を気に する傾向の強いことが一般的にいわれており，人目にふ れやすいエピテーゼの受容においては心理的な因子も無 視できない。本報告では，典型的な治療成功例と失敗例 とを対比して, エピテーゼの受容に関る心理的な要因を 検討した。

症例 1 は現在43歳の男性で，28歳㭙に悪性腫榢のため に左眼窩内容除去後，エピテーゼの限界を納得しつつ， 14年間にわたりエピテーゼの装用を続けている。これに 対して症例 2 は，生後閒もなく事故により右眼球を失っ た18歳の女性である。本症例は，14幣時に当科にてエピ テーゼの製作を行い，治療者側には良好な結果を得たと 考えられたにもかかわらず，全く装用しなかった。

表に示す如く，両症例は㥞々な要因について対照をな した。すなわち，症例 1 が一流企業の要職にあり仕事に 生きがいをむつ男性であるのに対し，症例 2 は自己の形 成途上の思春期の女性であり，両者のセルフイメージに 汢大きな差があった。さらに症例 1 は，容貌の変形を依 まず，他人の視線や批評む気にならないと強い自我を示 したのに対し，症例 2 では対照的な解答を得た。エピテ 一ゼのもつ技術的限界から，その装用がかえって眼球欠 損を他者に暗示寸る可能性は否めないが, 症例 1 で法眼 球欠損を他者に知られてもかなわないとし，あるがまま の「ひらきな怙り」の人生観が窥われた。対して症例 2 はあくまでも知られたくないとした。またエピテーゼに 対する希望についても，症例1が現実的な内容であるの に対し，症例 2 注実現の困難なものであり，両者の要求 水準の違いが明らかであった。さらに Y-G 性格検查で は, 症例 1 は情緒安定䆅極型のD類に, 症例 2 は情緒安 定消極型のC類に分類された。

以上の対比から，エピテーゼの受容には，製作物の出 来ばえ以外に，患者の性格，自我，七ルフイメージ，さ らには人生観など，こころの問題の関与が示唆された。

一方，エピテーゼ治療を長期装用の期待される症例に 効率よく施すことは，治燎者执よび患者の双方にとって 益するところが大である。そこで我々は，治療前の時点 での患者の性格，行動，あるいは婄度などから，エピテ 一ゼの受容を予測することを, プロスペクティブな検討
を通して試みた。

まず治療前の Y-G 性格検查の所見を，装用群17例と 中止群10例との間で対比したところ，殿用群でD類の䫏 度が明らかに高く，逆に中止群では低く，積極的な性格 のむのにエピテーゼ装用の可能性の高いことが 示され た。

さらに，当科において治療前にルーチンに行っている 面接で用いているプロトコールの各項目と，エピテーゼ に対する满足度との 関連性の検討により, 「装用後の自 己の変化の予想」「性別」，職業の有無」をはじめとす る 8 項目で装用群と中止群の明確な判別の可能なことが 明らかにされた。これらの項目のうちでも「装用後の自 己の変化の予想」は，両群の判別における重みがずばぬ けて大きく，この項目に対して装用群の大多数が社会的 活動性の向上をはじめとするポジティブな予想をしたの に対し，中止群ではネガティブな予想が殆どであった。 また「性別」では男性に，「職業の有無」では無しとし たものにエピテーゼの受容がされやすいことも明らかに なった。

以上の所見から、これらの項目をエピテーゼ治療開始 前に患者に問うことにより，エピテーゼの受容の予測が 十分可能であると考えられた。

表 症例 1 扝よび 2 の対比

\begin{tabular}{|c|c|c|}
\hline & 1 & 2 \\
\hline 性 & 男性 & 女性 \\
\hline 年 & 43 歳 & 18歳 \\
\hline 職 & 一流企業部長 & 高校生 \\
\hline 欠 & $\mathrm{F}_{1} \mathrm{C}_{0}$ & $\mathrm{~F}_{1 \mathrm{~b}} \mathrm{C}_{0}$ \\
\hline 綗 & 全くなし & しじゅら \\
\hline 他人の視線 & 気にならない & しじゅう気になる \\
\hline 初 印 象 & こんなものか & おもちゃみたい \\
\hline 肉親の反応 & もとの顔に戻った & （会っていない） \\
\hline 周囲の批評 & 気にならない & しじゅ気になる \\
\hline 眼球の欠損 & 知られてもよい & 知られたくない \\
\hline 希 望 & 変色とかぶれの改善 & 辺縁をなくす \\
\hline $\mathrm{Y}-\mathrm{G}$ & D類 & C類 \\
\hline
\end{tabular}




\section{5. 上額欠損患者の䣡積装著前後における構音機能の検討}

海 野 智・川辺 良一・長田 道哉・増田元三郎

增田 正樹・藤田 浄秀 （横浜市立大学・口胵外科）

上䫑切除後の義影装着患者15例について，義顥装着前 後の発語明瞭度を検討した。

\section{検查方法}

発語明暸度検㭗は降矢の方法に準じ，検者 5 名の検查 結果のうち中間值を呈した 3 名の值を採用した。分析項 目は, 行, 列, 後続母音, 構音点, 構音方法について, 正解率及び韻聴傾向を比較検討した。また，上顎欠損様 式別に分類し，同様な項目を分析した。欠損粎式は， $\mathrm{HS}$ 分類に従い, $\mathrm{H}_{1} \mathrm{~S}_{0} 2$ 例, $\mathrm{H}_{2} \mathrm{~S}_{0} 1$ 例, $\mathrm{H}_{8} \mathrm{~S}_{0} 5$ 例, $\mathrm{H}_{4} \mathrm{~S}_{0} 5$ 例, $\mathrm{H}_{5} \mathrm{~S}_{0} 1$ 例, $\mathrm{H}_{6} \mathrm{~S}_{1}$ 1例であった。

結 果

発諱明瞭度值は各症例を平均して, 装着前 $35.2 \%$ が, 装着後 $89 \%$ に改善した。装着前, $\mathrm{H}_{1} \mathrm{~S}_{0}$ 症例は $71.5 \%$ と 障害は軽度であったが, $\mathrm{H}_{2} \mathrm{~S}_{0}$ 及び $\mathrm{H}_{4} \mathrm{~S}_{6}$ 症例は $20 \%$ 以 下と高度であった。装着後は，久損様式による差は認め られなかった。行に関しては，装着前は，フ行，八行の 障害は軽度であったが, パ行, ダ行などの潈音, チャ行 等の拗音及びタ行の障害が高度であった。装着後では， パ行, ガ行, ヒャ・ビャ行の明瞭度值は他の行に比し低 值を示した。列に関しては, 義預装着前は, イ列, ウ列, 工列，才列， ア列の順に障害が強く， $\mathrm{H}_{2} \mathrm{~S}_{0}$ 及び $\mathrm{H}_{4} \mathrm{~S}_{0}$ 症例のイ列の発語明瞭度值は $5 \%$ 前後であった。装着後 は, 各列ともに, $90 \%$ 前後に改善された。後続母音に関 しては, 装着前で, [イ],[エ],[ウ],[オ], [ア]の 順に障害が鱽く，證聴傾向としては，〔イ〕は $42.2 \%$, [エ〕は12.2\%，〔ウ]に歪んでいた。欠損様式別では， $\mathrm{H}_{1} \mathrm{~S}_{0}$ 症例江 [工], $\mathrm{H}_{2} \mathrm{~S}_{0}$ 症例は [イ], [エ], [ウ], $\mathrm{H}_{8} \mathrm{~S}_{0}$ 症例住 [1]，[ウ]， $\mathrm{H}_{4} \mathrm{~S}_{0}$ 症例梳 [1]，[工]， $\mathrm{H}_{5} \mathrm{~S}_{0}$ 及び $\mathrm{H}_{6} \mathrm{~S}_{1}$ 症例では [イ]に障害が強かった。 次に, 調音点別では, 装着前は, 声門音以外法障害され ており，特に口蓋化音が著しかった。欠損様式別では， $\mathrm{H}_{2} \mathrm{~S}_{0}$ 症例のすべての音と $\mathrm{H}_{5} \mathrm{~S}_{0}$ 症例の硬口蓋音, 軟口 蓋音, 声門音の障害は軽度であったが，他の症例では， 声門音以外は高度に障害されていた。特に $\mathrm{H}_{2} \mathrm{~S}_{0}$ 症例の 齒音, 口蓋化音で障害が著明であった。装着後柱，各音 とも 84 95\%に改善されたが, $\mathrm{H}_{3} \mathrm{~S}_{0}$ 症例の口蓋化音, $\mathrm{H}_{4} \mathrm{~S}_{0}$ 症例の欶口蓋音は，他の音に比し，低值を示した。 調音方法別では，装着前は，破擦音・破裂音傽害が多 かった。摩擦音・通鼻音に障害が少なかった。装着後は 破擦音の改善が著明であった。

\section{考 察}

上頻欠損患者の場合，鼻咽腔閉鎖不全と広範国にわた る調音点の薄失のため, 高度言語障害を呈するが，良好 な義頻を装着することにより，ごく軽度な言語障害に改 善される。自験例でも発語明膫度值は装着前 $35.2 \%$ が装 着後 $89 \%$ と良好に改善された。佐川らは，発語明瞭度検 查を用い，HS 分類で硬口蓋及び歯槽部の欠損Hが大き 、程，義影装着後の構音機能の回復は不良となると報告 しているが，自験例では，義頻装着後には，口蓋欠損に よる差は認められなかった。行に関しては，各欠損様式 を通して，パ行の障害が義影装着前後ともに強かった。 パ行, バ行の発語明膫度值は, 後天的上顥欠損時におけ る章咽腔閉鎖機能の指標となるとの報告もあり，義影に よる構音機能の回復の診断に臨休的で簡便 ・有用な検查 と考えられた。列においては，人列の障害が著明であっ た。鉒本は，レ線的観察による母音発声時の舌の位置に より，硬口盖の母音構成に影㚳する順序は，[1]，[エ]， 〔ウ]，[オ]，[ア〕の順であると報告している。自験例 に抢いても，義顥装着前には，後繶母音 [イ]，[エ]に 高度な障害があったが，装着後は〔イ〕，[エ〕の正解率 が $98 \%$ 以上になり，生理的な口蓋形態が義䫓により付与 されたためと考えられた。調音点別では, 装着前, $\mathrm{H}_{5} \mathrm{~S}_{0}$ 症例で，硬口蓋音・軟口㸃音の障害が軽度であったが， これは，自験例の $\mathrm{H}_{5} \mathrm{~S}_{0}$ 症例が前方部欠損であるためと 思われる。装着後注, 軟口蓋の改善が他の音に比し不良 であり，特に $\mathrm{H}_{4} \mathrm{~S}_{0}$ 症例で障害が強かった。これは, $\mathrm{H}_{4} \mathrm{~S}_{0}$ 症例の場合, 義類の後緣方硬軟口蓋境界部に位置 し, 軟口蓋の動きを障害するためと思われる。調音方法 別では，装着前，破裂音の障害が高度である報告が多い が，自験例では破裂音以上に破擦音の障害が高度であっ た。これは, 破擦音は, 摩擦音の初めに破裂的要素が加 ふっているが，装着前俚高度な鼻咽䐋開鎖不全のため に，この微妙な破裂的要素を調音できないためであると 思われる。しかし, 義影装着後, 閉鎖不全がごく軽度に なるので，破擦音の明膫度は $95.7 \%$ と著明に改善した。 これに対し，破裂音は，義影装着後でむ，多少閉鎖不全 が残存していると，それが忠実に反映されるようで，明 膫度は84.5\%であった。

今後症例を増し，更に検討を加える予定である。 


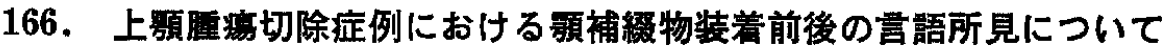

\author{
大澤 毅明・鈴木 規子・今井 智子・山下夕香里 \\ 舘野 孝行・長谷川昌宏・大野 康亮・道 健一
}

(昭和大学・第 1 口䐋外科)

斉藤 謷・田中 収・竹内 敏郎

(同・第 2補緅学)

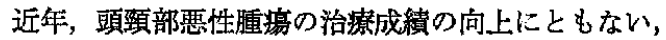
患者の社会復帰をはかるためのリハビリテーションが重 要な問題となっている。

われわれは各種の上顎切除䛧を施行した症例に対して 顎補叙物を応用した 機能障害回復の治療を行っている が，今回は術後の機能障害のうち，特に言語障害につい て頢補緅物装着前後の改善過程を空気力学的検查法, 鼻 咽膯ファイバースコープ法, 発語明膫度検查法によって 検索したので報告した。

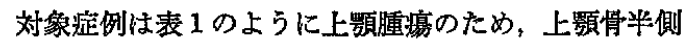
全切除術，両側上䫁骨部分切除術および軟口蓋を含めた 上頻骨部分切除術などを施行し，䫓補叕物を装着した 6 症例である。性別は男性 5 例, 女性 1 例, 年龄は31歳か ら81歳で平均年崳56.5歳であった。組織型別では, 扁平 上皮㴖 4 例, 悪性多形性腺腫 1 例, clear cell tumor 1 例であった。頡補経物の装着時期は術後 3 カ月か カ月で平均10.3カ月であった。手術範囲は表 1 に示すよ 亏に上頻骨半側全切除術 2 例, 上頻骨部分切除術 2 例, 軟口蓋の $1 / 3$ を含む上影䯈部分切除術 1 例, 両側上類骨部 分切術街 1 例であった。

装着した湏補緅物は次の通りである。

症例 $1 ：$ 天蓋開放型, スピーチエイドタイプ

症例 2 : 中空型, スイングロックアタッチメント

症例 3 : 天蓋開放型, スイングロックアタッチメント 症例 $4:$ :蓋開放型（無遴影）

症例 5 : 天䔔開放型，コースステレスコープシステム 症例 6 : 天蓋開放型, エーカースクラスプ

鼻咽腔ファイバースコープ所見では，曣下時に全症例 とも勫咽胵の完全開鎖が得られた。また症例 1 以外は算 咽腔部に直接手術㡎襲を加えていないにもかかわらず，
頻補仯物装着前には soft bowing 時, 発音時などに鼻 咽腔閉銷不全が認められた。しかし影補緅物装着後は明 らかに鼻咽腟閉鎖機能の改善が認められた。

ネーザリティーフローグラフィーによる影補緅物装着 前後の口胵舅腔遮断の程度を空気力学的に検討したとこ ろ，、ずれの症例も影補緅物装着により鼻腔漏出気量が 減少する傾向を示し，特に口腔内圧を必要とする子音 〔P][S]で著明な改善が認められた。

10 人の検者による日本語 100 語節の発語明膫度検查結 果では，影補緅物装着前俚平均正答率 $13.2 \sim 52.7 \%$, 平

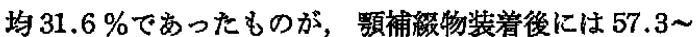
$93.8 \%$, 平均 $81.4 \%$ と著しく改善された。構音点別検査 結果では，額補䊉物装着前には声門音を除いて著しい障 害が認められ，久損部位との関連をみると; 構音点が欠 損部位に相当する硬口蓋音，歯音，歯茎音のみならず， 構音点が久損部位と無関俰な口唇音, 軟口蓋音にも著し い障害が認められたが，顎補疑物装着後は口虞の閉鎖機 能が不十分な症例 2 の口唇音を除いて全般的に著しい改 善がみられた。子音の構音様式別検查結果では，顎補耀 物装着前には破裂音，破擦音に著しい障害が認められた

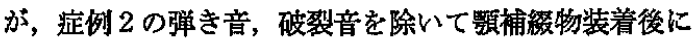
$50 \%$ 以上と改善された。母音別検查結果では，全体的に 障害が比較的軽度であったが，[i][e]【w]に障害が みられ，特に高度の開口障害と口唇の閉鎖不全を伴った 症例 2 では，[e, w, ai] の順で障害が認められたが， 影補緅物装着後はいずれの症例です著しく改善された。

以上の上うに上蝢切除後の発音障害㹥重度であるが， 症例に応じた影補緅物の製作によって著しい改善が得ら れることは，患者のリハビリテーションにとって，䫑補 稀物装着の意義が極めて大きいといえる。

表 1 対 象 症 例

\begin{tabular}{|c|c|c|c|c|c|c|}
\hline 症例番号 & 性別 & 年齢 & 臨床䛦断 & 病理診断 & 手術 術式 & 補緅物装着時期 \\
\hline 1. (K. S.) & 字 & 34 & 右上顥腫痬 & 覀性多形性腺腫 & 右上顎骨部分切除術 & 11カ月 \\
\hline 2. (Y.M.) & 占 & 31 & 左上䫟腫瘍 & 扁平上皮癌 & $\begin{array}{l}\text { 左上顎骨半側全切除術 } \\
\text { 左頸部全廓清術 }\end{array}$ & 2 年 2 力月 \\
\hline (K. S.) & 客 & 61 & 上類腫瘍 & Clear cell tumor & 両側上影骨部分切除術 & 3 カ月 \\
\hline 4. (E. Y.) & 今 & 70 & 右上頍腫傷 & 扁平上皮癌 & $\begin{array}{l}\text { 右上顎骨半側全切除術 } \\
\text { 右新部全㢌清術 }\end{array}$ & 6 カ月 \\
\hline 5. (F.Y.) & 우 & 81 & 右上顎腫瘍 & 扁平上皮澏 & 右上頻骨部分切除術 & 9.5 力月 \\
\hline 6. (T. T.) & $\uparrow$ & 62 & 右上頝腫演 & 扁平上皮癌 & 右上頑骨部分切除術 & 6 力月 \\
\hline
\end{tabular}




\section{7. 顎顔面欠損患者の音声学的検討}

宇澤俊一・白川正順 - 長谷川秀行（町田市民病院・ 口腔外科）

田辺 睛康

(慈恵医科大学・歯科)

硬，軟口蓋なよび顔面欠損は，音声に大きな影響を与 えますが，久損部位，範囲の程度によって構音障害は異 なっている。

今回，私たちは口蓋欠損と顔面欠損の範团を分類し， 欠損範囲と発語明瞭度 (語明度) との関係を検索したと ころ, 若干の知見を得たので報告した。検索対象は，上 顎腫埴摘出後, 口蓋欠損, 顔面欠損により構音障害を認 めた44歳から72歳までの男性 6 例, 女性4例の計10例で, そのうち顔面欠損を伴うものは 5 例であった。また，こ れらの義影はいずれむ軽量化をはかった天蓋開放型であ った。模查法は, 日本語の 5 母音と20子音について 67 単 音節を無作為順序で発声させ判定した。

\section{結 果}

義類装着前では， $10 \% \sim 48.2 \%$ 語明度であったが， 義颉装着後では，73\% 100\%と明らかな語明度の改善 を認めた。また，F欠損症例と $\mathrm{F}$ 欠損を伴わない症例の 平均值をみると，F矢損群では，義䫑装着前後ともに低 い值を示したが，F矢損を伴わない群との差は約 $8 \%$, 装着後では約 $6 \%$ と著明な差を認めなかった。次に，症 例を HS 分類に従って各群に分類し比較検討してみる と，図 1 にみられるごとくである。斜線部は，義頻装着 前を示し, 刷部分は装着後を示す。各群内に挌いて義領 装着前で語明度は，F欠損症例の方が低く，装着後では 症例 4 を除き装着前と同様に, $\mathrm{F}$ 欠椇症例の語明度は低 い值を示す倾向がみられた。特に，100\%の語明度を得 た 4 と HS 分類でほぼ同様の症例 3 とを比較すると， $\mathrm{F}_{123}$ と大きな欠損を持つ症例 4 が高い值を示し， $\mathrm{F}$ 久損 の大小に必ずしも関連していない結果を得た。さらに， HS 分類の群別について検索すると, 義顥装着前のF欠 損を伴わない症例では，HS 久損が大きくなるととも に, 語明度も低くなり，F欠損症例では必ずしもその傾 向を認めなかった。装着後での比較では，F欠損症例， F欠損を伴わない症例ともに, HS 久損の大小に比例し
ない結果を得，これらの検索より少ない症例で十分と言 えないが，HS 分類および FC 分類と語明度との関連 性に一つの傾向は諗められるが，断言するにいたらなか った。

次に，義顥装着の 5 母音，20子音の各音について，障 害程度を検索すると，障害は総体的にみられ，子音では 破裂音, 破擦音がもっとも強く, 摩擦音における硬口蓋 音, 弾音が中等度に障害された。母音は，子音に比較し て障害程度は小さかった。以上まとめると，

1. 義影装着後に明らかな，語明度の改善がみられた。

2. 語明度と HS, FC 分類との関連性恃必ずしも認 めなかった。

3. すなわち, 語明度の条件は, HS, FC 分類の二次 元的形態だけに左右されず，久損の内部構造ならびに箐 囲にも関係すると推察された。

4. 語明度の良否は, 義顎に対する患者のなれ，義顎 の形態によって左右されると考えられた。

今後, さらに義影の形態，個体差などを含め，HS， $\mathrm{FC}$ 欠損と内部構造との関係について検索して行く所存 である。

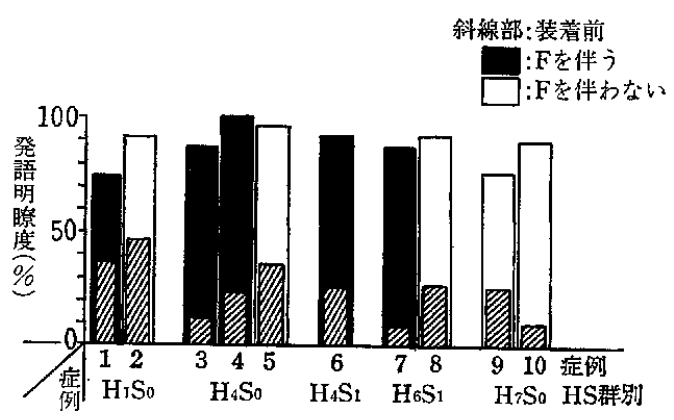

図 1 発語明膫度と HS 群別との関保 


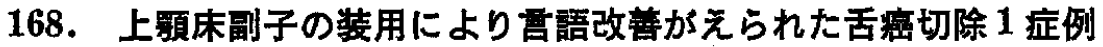

\author{
糟谷 政代・水野 伸彦・脣 山 勝・金田 敏郎 \\ (名古屋大学・口腔外科)
}

舌癌切除後, 即㭙再建に用いた大胸筋皮弁の萎縮によ り，官語障害を後邀した 1 症例に，言語の改善を目的と して，上頧に発音補助用のプレート装着を試みた。プレ 一ト装着 1 力月後に, 語音発語明膫度検查, ソナグラム・ 静的パラトグラム, 発声の能力に関する検查などを杞こ ない，言㽬の改善傾向を検討した。

症例は36歳女性。某罣立病院より舌痛精查のために来 院。精查の結果は $\mathrm{T}_{3} \mathrm{~N}_{1} \mathrm{M}_{0}$ の舌扁平上皮癌であった。 術前には放射線療法 ( $\left.{ }^{\circ 0} \mathrm{Co} 40 \mathrm{~Gy}, \mathrm{Ra} 30 \mathrm{~Gy}\right)$ と化学療 法 (DEP 170mg, ピシバニール115KE, 5-FU 2300mg)

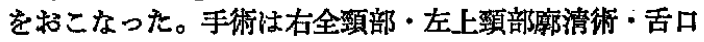
底部分切除術，舌3/4切除術を施行し，大胸筋の皮弁で 即時再建をおこなった。術後 1 カ月目では移植皮弁のボ リュームむ保たれ，語明度も良好でコミニケーションに はあまり支障がみられなかった。しかし，徐々に移植皮 弁の萎縮がみられ，語明度も低下していった。そのため 術後 1 年 5 カ月目にプレートを装着した。

結 果

プレート装着 1 カ月時点での語明度は（除去時・装着 時)单音 $11.3 \%, 20 \%$, 単語 $23.5 \%, 41.6 \%$ と装着時に注向 上した。文章や会話では除去時には一単音つつ区切って 発声し, 覑回な息つぎや努力性の発声のために十分なュ ミニケーションがとれない状熊であった。けれどむ装着 時には，リズムにまとまりがみられるようになり，話題 を知っていればコミニケーションも楽にとれるようにな った。そして，母音では [O] を除く 4 母音は良好とな
り，各子音の向上もみられた（表 1)。特に, 两唇破裂音 $\mathrm{P}$ 行 $\mathrm{b}$ 行, 歯菱通鼻音 $\mathrm{n}$ 行, 硬口篮摩擦音 $\mathrm{j}$ 行, 声門摩擦音 $\mathrm{h}$ 行などの語明度は良好となった。ソナグ ラムの検索ではプレート装着の有無にかかわらず，母音 ホルマント周波数は 正常女子のに比らべ異常值を示し た。子音では子音部の表出がプレート装着時には多少み られる単音もでてきて, 特に na, ma, wa, pa, ha, Ji は正常パターンと近似した。静的パラトグラムでは, 正 常パターンとやや異なるが, 歯茥音 ta, na, ra, $f$, ts,

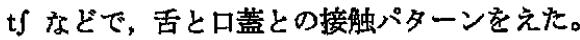

発声の能力に関する検查では，舌運動は舌尖举上や左 右口角静止，前挺出はできず，わずかに舌全体で举上が 可能であった。[a:] の発声持続時間は除去時には最大 9 秒, 装着時には11.5秒でわずかに延長し, 異常值より 脱却した。肺活量は除去時の最大 $1900 \mathrm{cc}$ から装着時に は最大 $2650 \mathrm{cc}$ と多くなったが, $\mathrm{PQ}$ 值はどちらむ $222 \mathrm{~m} l /$ sec で異常値を示した。これら異常值の原因は, 声門閉 鎖不全と関係するといわれている。乙かし，本症例の場 合には奥舌部の高さが皮弁側がわが異常に低く，そのた め口膑内圧を十分高めたり，呼気流速の調整をおこなう ことができないためであると考えられた。

本症例のごとく，発音補助用のプレート装着により， 固有口腔の形態を変化しせて（口腔内容積 : 除去時35 $\mathrm{ml}$, 装着時 $24 \mathrm{~m} l)$ 言語改善をえられたことは, 同様な重 度言語障害症例の言語改善のために，有用な 1 手段とし て使用できることを示唆した 1 症例であると考えた。

表 1 子音: 铻音 明瞭度

\begin{tabular}{|c|c|c|c|c|c|c|c|c|c|c|c|c|c|c|c|c|}
\hline 呼気榜 & & 構音点 & 両 & 唇 音 & 宷 & 音 & 崡 & 荃 音 & 硬卜 & 口蓋音 & & 蓋音 & 声 & 門 音 & Plate (-) & Plate (+) \\
\hline & 破 & 無 声 & $\mathbf{p}$ & $\begin{array}{c}0 \% \\
20.0\end{array}$ & & $\%$ & $t$ & $\begin{array}{l}0 \% \\
5.0\end{array}$ & & $\%$ & $\mathbf{k}$ & \begin{tabular}{ll|}
0 & $\%$ \\
0 & \\
\end{tabular} & & $\%$ & $0.1^{\%}$ & $8.3^{\%}$ \\
\hline & 喑 & 有 声 & $\mathrm{b}$ & $\begin{array}{l}13.3 \\
85.0\end{array}$ & & & d & $\begin{array}{l}0 \\
0 \\
\end{array}$ & & & $\mathbf{g}$ & \begin{tabular}{l|l}
0 \\
0
\end{tabular} & & & 5.1 & 30.4 \\
\hline 子 & 通 & 無 声 & & & & & & & & & & & & & & \\
\hline & 基 & 有声 & $\mathrm{m}$ & $\begin{array}{l}35.0 \\
50.0 \\
\end{array}$ & & & $\mathbf{n}$ & $\begin{array}{r}0 \\
25 \\
\end{array}$ & & & $y$ & & & & 20.0 & 37.5 \\
\hline & 摩 & 無 声 & $\mathrm{F}$ & $\begin{array}{l}33.3 \\
25.0 \\
\end{array}$ & $\mathrm{~S}$ & $\begin{array}{l}5.0 \\
5.0 \\
\end{array}$ & $\int$ & $\begin{array}{l}0 \\
0\end{array}$ & c & $\begin{array}{c}33.3 \\
100 \\
\end{array}$ & & & h & $\begin{array}{l}33.3 \\
66.7 \\
\end{array}$ & 15.4 & 31.8 \\
\hline . & 撜 & 有 声 & $W$ & $\begin{array}{r}0 \\
100\end{array}$ & $z$ & & & & $\mathbf{j}$ & $\begin{array}{l}11.1 \\
41.7 \\
\end{array}$ & & & & & 8.3 & 56.3 \\
\hline 竞 & 破 & 無 声 & & & ts & $\begin{array}{c}0 \\
25.0 \\
\end{array}$ & $t \int$ & $\begin{array}{l}0 \\
0 \\
\end{array}$ & & & & & & & 0 & 12.5 \\
\hline 夏 & 璒 & 有 声 & & & $\mathrm{d} z$ & $\begin{array}{l}0 \\
0 \\
\end{array}$ & $\mathrm{dz}$ & & & & & & & & 0 & 0 \\
\hline & 弹 & 無 声 & & & & & & & & & & & & & & \\
\hline & 音 & 有 声 & & & & & $I$ & $\begin{array}{l}0 \\
5.0 \\
\end{array}$ & & & & & & & 0 & 5 \\
\hline & ate ( & & & 17.8 & & 2.6 & & 2.1 & & 16.7 & & 0 & & 3.3 & & I \\
\hline & ate ( & & & 52.9 & & 4.5 & & 10.0 & & 56.3 & & 0 & & 6.7 & I & \\
\hline
\end{tabular}

